Article

\title{
Hydrogen Purification from Compact Palladium Membrane Module Using a Low Temperature Diffusion Bonding Technology
}

\author{
Duck-Kyu Oh ${ }^{1,2}{ }^{\oplus}$, Kwan-Young Lee ${ }^{1}$ and Jong-Soo Park ${ }^{2, *}$ \\ 1 Department of Chemical and Biological Engineering, Korea University, 145 Anam-ro, Seoul 02841, Korea; \\ ohdk@kier.re.kr (D.-K.O.); kylee@korea.ac.kr (K.-Y.L.) \\ 2 Energy Conversion \& Storage Materials Laboratory, Korea Institute of Energy Research, 152 Gajeong-ro, \\ Daejeon 34129, Korea \\ * Correspondence: deodor@kier.re.kr; Tel.: +82-42-860-3667
}

Received: 15 October 2020; Accepted: 9 November 2020; Published: 12 November 2020

\begin{abstract}
This study investigates a compact palladium membrane module (CPMM) for hydrogen purification, assembled by diffusion bonding at a low-temperature $\left(450{ }^{\circ} \mathrm{C}\right)$. This $\mathrm{CPMM}$ resulted in hydrogen $\left(\mathrm{H}_{2}\right)$ flux of $18.3 \mathrm{~mL} \mathrm{~cm}^{-2} \mathrm{~min}^{-1}$ with $\mathrm{H}_{2} / \mathrm{N}_{2}$ selectivity of over 1100 . The $\mathrm{H}_{2}$ purification test using a $60 \% \mathrm{H}_{2} / 40 \% \mathrm{CO}_{2}$ mixed gas confirmed that the CPMM can separate $\mathrm{H}_{2}$ with a concentration of more than $99 \%$, with a pressure difference of 5 bar. Moreover, the volume of the diffusion bonded membrane module is decreased by $81.4 \%$ than the flame-type membrane module pre-studied in our laboratory.
\end{abstract}

Keywords: hydrogen; carbon dioxide; purification; palladium membrane; compact module; diffusion bonding

\section{Introduction}

High-purity $\mathrm{H}_{2}$ gas is required for many chemical, industrial, and electronic applications such as ammonia production, steel and glass manufacture, and electrical generator cooling, respectively. Since it is nontoxic and an efficient fuel source, $\mathrm{H}_{2}$ is considered a clean energy carrier [1,2]. Fuel cell systems also require high-purity $\mathrm{H}_{2}$ for portable power. Consequently, the demand for high-purity $\mathrm{H}_{2}$ is increasing $[3,4]$.

Hydrogen can be produced from fossil fuels by thermochemical processes like steam reforming of natural gas and by various water-splitting methods, e.g., thermochemical, photo-electro -chemical, photo-biological, and electrolysis. Over $95 \%$ of $\mathrm{H}_{2}$ gas is produced from fossil fuels [5]. Hydrogen production from fossil fuels typically comprises four steps: Desulfurization, high-temperature shift reaction, low-temperature shift reaction, and $\mathrm{H}_{2}$ purification [6,7]. The produced hydrogen can be purified via pressure swing adsorption (PSA), cryogenic distillation, and membrane separation. Among these, the PSA and cryogenic distillation methods are commercially available [8,9]. However, they are both intensive in terms of technical expertise, energy, and infrastructure requirements during operation [10,11]. The membrane separation technique has relatively low energy and cost requirements during operation. Furthermore, palladium membranes are excellent for $\mathrm{H}_{2}$ separation and purification because of their high permeability and high selectivity for $\mathrm{H}_{2}$ [11-13]. The hydrogen separation mechanism of the palladium membrane is basically depending on the hydrogen partial pressure. The Hydrogen molecules were dissociated into hydrogen atoms at the surface of the palladium membrane, and then diffusion into the palladium membrane. The separated hydrogen atoms through the membrane were recombined with hydrogen molecules on the opposite surface [14]. 
When using palladium based dense membranes, the design and configuration of the membrane module are critical for successful application in $\mathrm{H}_{2}$ separation and purification. In particular, the configuration of compact modules is necessary in small-scale $\mathrm{H}_{2}$ purification. Membrane modules can be divided into the several types depending on the membrane shape, e.g., flange [15-17] and tubular $[11,13,15,18,19]$ modules. Though it may be easy to scale-up these membrane modules, ensuring compact module configuration poses difficulty.

Micro channel reactors (MCRs) are advantageous in terms of their considerable heat and mass transfer, large surface-area-to-volume ratio, compactness, and easy integration [20]. This paper reports for the first time the application of an MCR in configuring a compact and multi-stackable membrane module. For this purpose, it is vital to examine the methods for effectively assembling stainless steel (SS) components to prepare the MCR module. Typically, diffusion bonding was performed at a high-temperature $\left(>1000{ }^{\circ} \mathrm{C}\right)$ using $316 \mathrm{~L}$ SS in order to obtain a compact palladium membrane module (CPMM) [21]. However, because of the exposure of the CPMM to the harsh conditions of high-temperature and high vacuum, defects can be generated within the palladium membrane during its preparation. Therefore, the plate surfaces were modified such that the diffusion bonding could be performed at a low-temperature $\left(450{ }^{\circ} \mathrm{C}\right)$ to ensure minimum damage to the palladium membrane. The module performance test was performed to determine the feasibility of the CPMM. The above-mentioned $\mathrm{H}_{2}$ separation and purification modules has disadvantages in terms of scale-up and compactness due to their complicated structure and design. accordingly, we designed an MCR type $\mathrm{H}_{2}$ separation and purification module to provide easy assembly and compact with diffusion bonding technology.

\section{Materials and Method}

\subsection{Design and Manufacture of the CPMM}

The palladium based membranes were manufactured by our laboratory using the preparation procedures explained in a previous work $[22,23]$. Palladium was deposited on the prepared Porous nickel support (PNS) $(49.3 \mathrm{~mm})$ at $450{ }^{\circ} \mathrm{C}, 20$ mTorr under Ar using a DC/RF magnetron sputter (Korea Vacuum Tech Co., Ltd., Daegu, Korea). Then, polishing and heat treatment were performed to produce a dense palladium membrane with improve selectivity. Figure S1 shows the cross-section SEM image of palladium membrane. The estimate thickness of palladium membrane layer was $2.7 \mu \mathrm{m}$. The constituents of the CPMM are shown in Figure 1. The module is composed of etched 316L SS plates (a, b), a palladium membrane (c), a Cu foil (d), and a Ag gasket (e). The 316L SS plates were chemically etched with various channels and holes. Figure 2 shows the components and gas path (retentate stream (G-1) and a permeate stream (G-2)) in the CPMM. The designed 316L SS plates consist of a cover plate (two sheets) of $1 \mathrm{~mm}$ thickness, a feed gas distribution plate (G-1-1), a plate for protection of the knife-edge (G-1-2), a knife-edge plate for membrane sealing (G-1-3), a membrane holder plate (G-1-4 and G-2-2), and permeate gas collection plates (G-2-1). Three-dimensional (3-D) porous channels were formed on the G-2-1 plate to sufficiently distribute the permeate gas through the Palladium membrane. 


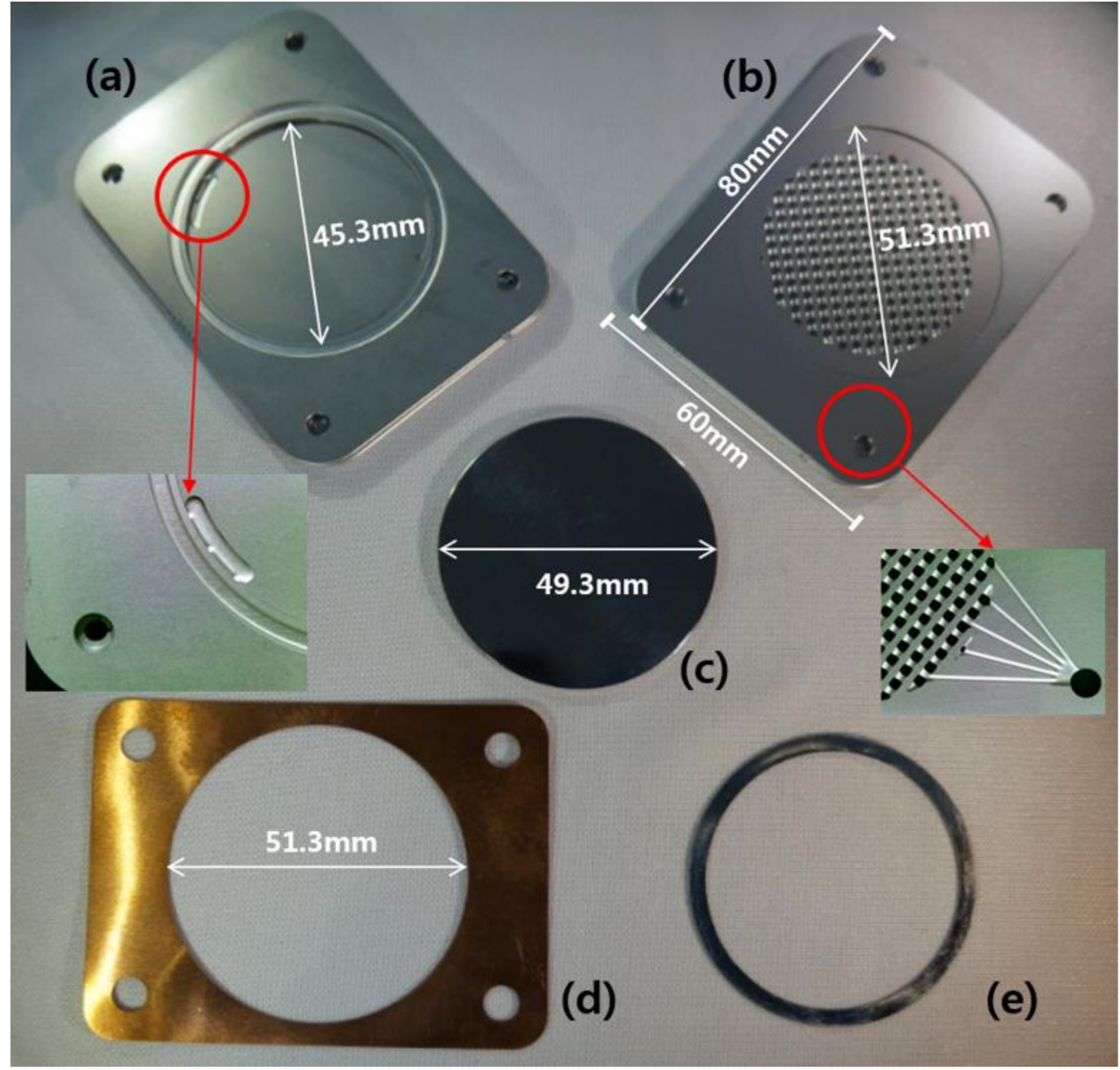

Figure 1. Constituent photographs of compact palladium membrane module (CPMM); etched 316L stainless steel (SS) plates of (a) feed stream and (b) permeate stream, (c) disc-shaped Pd-based membrane, (d) Cu foil, (e) Ag gasket.

The G-1 and G-2 groups were modified using the following method to decrease the diffusion bonding temperature and to easily assemble components.

(1) Each G-1 and G-2 part was diffusion bonded using hot-press (Samyang Ceratech Co., Ltd., Incheon, Korea) under high vacuum $\left(3.0 \times 10^{-6} \mathrm{Torr}\right)$ and $900{ }^{\circ} \mathrm{C}$

(2) The surfaces of bonded G-1 and G-2 (G-1-4 in G-1 and G-2-2 in G-2) were peened using a peening machine (IEPCO PEENMATIC 550, Swiss Instruments Limited Co., Ltd., Mississauga, Canada) to increase the surface roughness using 316L SS powder by spraying method.

(3) Ni and $\mathrm{Cu}$ were deposited over the peened surfaces of the G-1 and G-2 using the DC magnetron sputtering method.

(4) G-1 and G-2 with $\mathrm{Ni}$ and $\mathrm{Cu}$ deposition were thermally treated under $\mathrm{H}_{2}$ condition at $700{ }^{\circ} \mathrm{C}$ for $2 \mathrm{~h}$ in the muffle furnace.

We analyzed the morphology, average surface roughness, and surface area of the modified surfaces using a color confocal microscope (H1200, Lasertec Co., Ltd., Hwa-seong, Korea). The CPMM was completed by diffusion bonding with modified G-1 and G-2, Cu foil (thickness $0.4 \mathrm{~mm}$ ), Ag gasket (thickness $0.25 \mathrm{~mm}$ ), and Palladium membrane. The diffusion bonding was performed at $450{ }^{\circ} \mathrm{C}$ for $5 \mathrm{~h}$ under high vacuum $\left(3.0 \times 10^{-6}\right.$ Torr $)$ and 20 Ton in the hot press. The leak test of the CPMM was performed at a pressure difference of 5 bar at room temperature. 


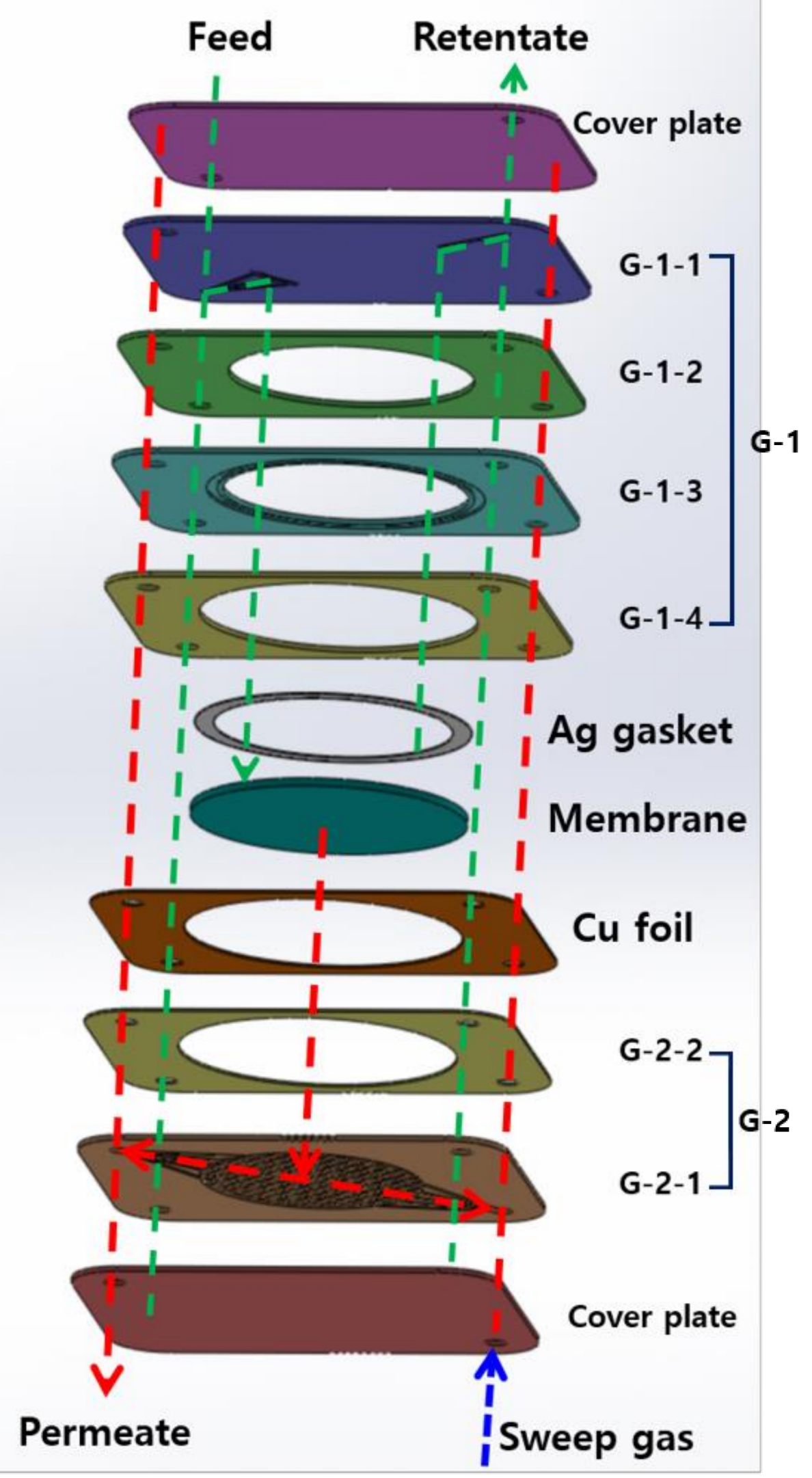

Figure 2. The components and gas path in the CPMM; Green line: Feed stream gas path, Red line: Permeate stream gas path. 


\subsection{Permeation Test Method of Hydrogen}

The photograph of the diffusion bonded CPMM is shown in Figure 3a. Feed gas was introduced to the membrane through the G-1 group. Then, the permeated gas through the membrane was an exhaust-to-permeation stream through the G-2. The photograph of $\mathrm{H}_{2}$ permeation apparatus for the permeation experiment was shown in Figure 3b. The diffusion bonded CPMM was fixed and connected with a SS tube. The CPMM was heated in an electric furnace with a programmable temperature controller. The temperature of the furnace was controlled by a k-type thermocouple placed close to the membrane surface in the retentate stream. To prevent phase transition of the palladium, $\mathrm{N}_{2}$ was supplied up to $300{ }^{\circ} \mathrm{C}$ [24]. The permeation rates of $\mathrm{H}_{2}$ and $\mathrm{N}_{2}$ as a single gas were measured by a digital soap bubble flow meter (Gilibrator, SENSIDYNE Co., Ltd., Petersburg, FL, USA) at a pressure difference of 1 to 20 bar and $400{ }^{\circ} \mathrm{C}$.
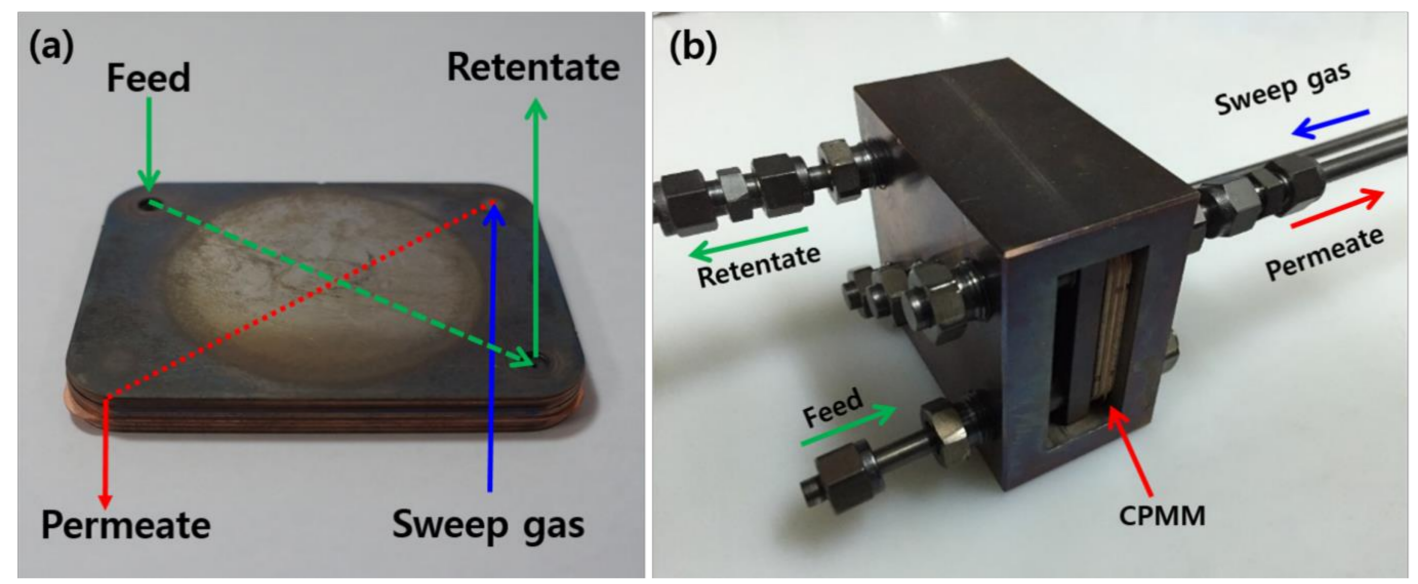

Figure 3. The photograph of (a) diffusion bonded CPMM and (b) the assembled $\mathrm{H}_{2}$ permeation apparatus.

We performed the $\mathrm{H}_{2}$ separation tests using the $\mathrm{H}_{2} / \mathrm{CO}_{2}$ mixture gas at a pressure difference of 1-20 bar and a temperature of $400{ }^{\circ} \mathrm{C}$ with a feed gas flow rate range of 1.0-1.5 $\mathrm{L} \mathrm{min}^{-1}$. We analyzed the $\mathrm{H}_{2}$ concentration of the permeate stream by Gas Chromatography. (G.C., 7890A, Agilent technology Co., Ltd., Santa Clara, CA, USA) equipped with a carboxen 1010 PLOT capillary column and thermal conductivity detector (TCD). Upon completion of the permeation testing, the membrane module was slowly cooled under $\mathrm{N}_{2}$. For cross-sectional analysis of the low-temperature diffusion bonded module, we used water-jet cutting and characterized the cut module by field emission scanning electron microscopy (FE-SEM, HITACHIS-4700).

\section{Result and Discussion}

\subsection{Characterization of Membrane and CPMM}

The average surface roughness $(\mathrm{Ra})$ and surface area of the pretreated G-1 and G-2 groups were analyzed using a color confocal microscope, and the results are presented in Table 1. As shown in Table 1, The Ra values and areas of the surfaces modified by peening, Ni-Cu deposition, and thermal treatment were significantly different from those of the fresh, non-treated surfaces of G-1 and G-2. The Ra value of the peened surface was significantly higher $(0.446 \mu \mathrm{m})$ than that of the fresh surface $(0.167 \mu \mathrm{m})$. The increases in surface roughness and surface area of G-1 and G-2 were directly associated with effective diffusion bonding. This association means that the components can be effectively diffusion bonding at the low-temperatures. As shown in Figure 4, the surface morphologies of G-1 and G-2 obtained at different stages of surface modification were analyzed using a color confocal microscope. Figure $4 \mathrm{a}-\mathrm{d}$ shows two-dimensional (2-D) surface images of the fresh and modified surfaces. After the peening process, the surface morphology showed higher surface roughness and surface area than those of the fresh surface morphology. Conversely, the surface morphology showed 
decreased surface roughness compared to the Ni-Cu-deposited surface by sputtering. Figure $4 \mathrm{e}, \mathrm{f}$ shows the 3-D morphology of the untreated and peened surfaces. After the peening process, many pin-points were observed on the surface compared to the untreated surface of plate. The generated pin-points, designated with red color, were subjected locally to very high pressure during the diffusion-bonding step, resulting in easy assembly between the G-1 and G-2 groups at low-temperatures.

Table 1. The surface properties of modified commissure by color confocal microscope.

\begin{tabular}{ccc}
\hline Process & Ra $(\mu \mathbf{m})$ & Surface Area $\left(\mathbf{m m}^{2}\right)$ \\
\hline Fresh & 0.167 & 0.128 \\
Peening & 0.446 & 0.132 \\
Ni-Cu deposition & 0.582 & 0.133 \\
Thermal treatment & 0.520 & 0.132 \\
\hline
\end{tabular}
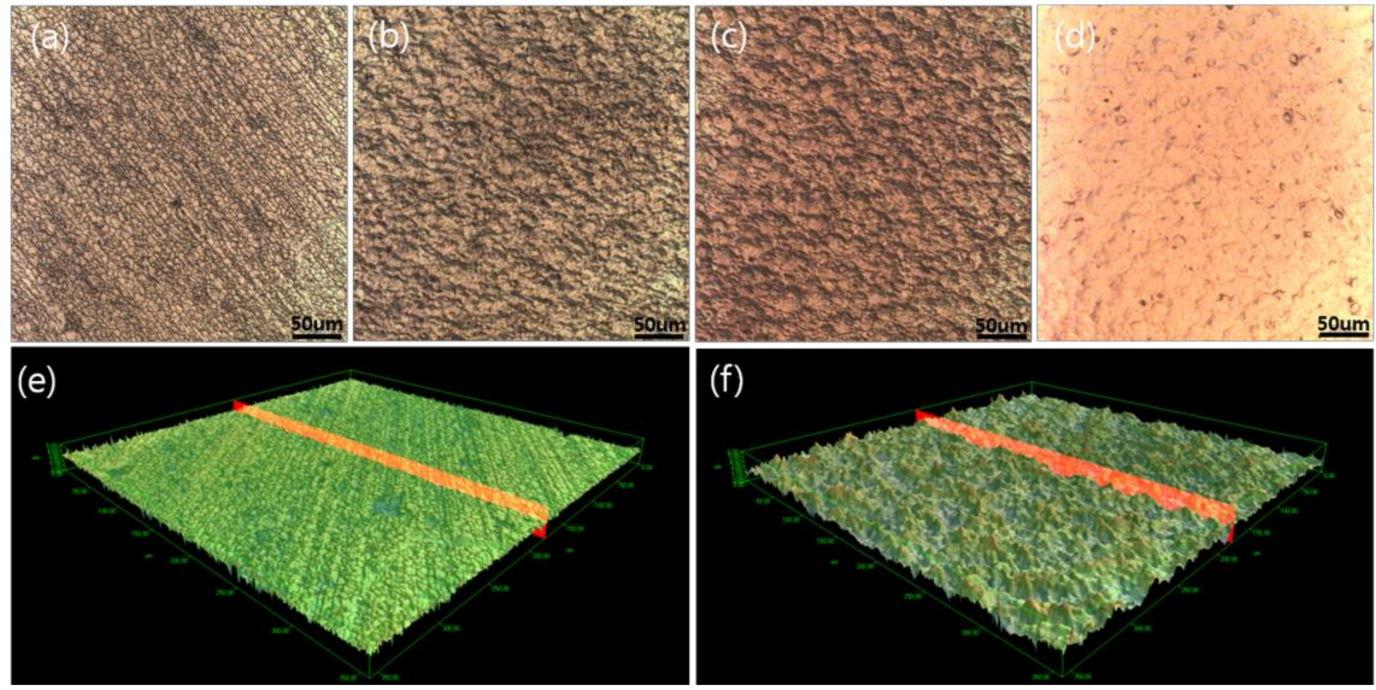

Figure 4. The surface image of modified 316L SS plate by color confocal microscope; 2-D image: (a) Fresh, (b) peening, (c) Ni-Cu deposition, (d) thermal treatment; 3-D image: (e) Fresh and (f) peening.

Figure 5 shows the cross-sectional image of the CPMM. As shown in Figure 5a, the height of assembled module was obtained $7.9 \mathrm{~mm}$. Figure $5 \mathrm{~b}$ shows the low-temperature bonded layers between the G-1 and $\mathrm{Cu}$ foil and the G-2 and $\mathrm{Cu}$ foil can be seen to be defect free.
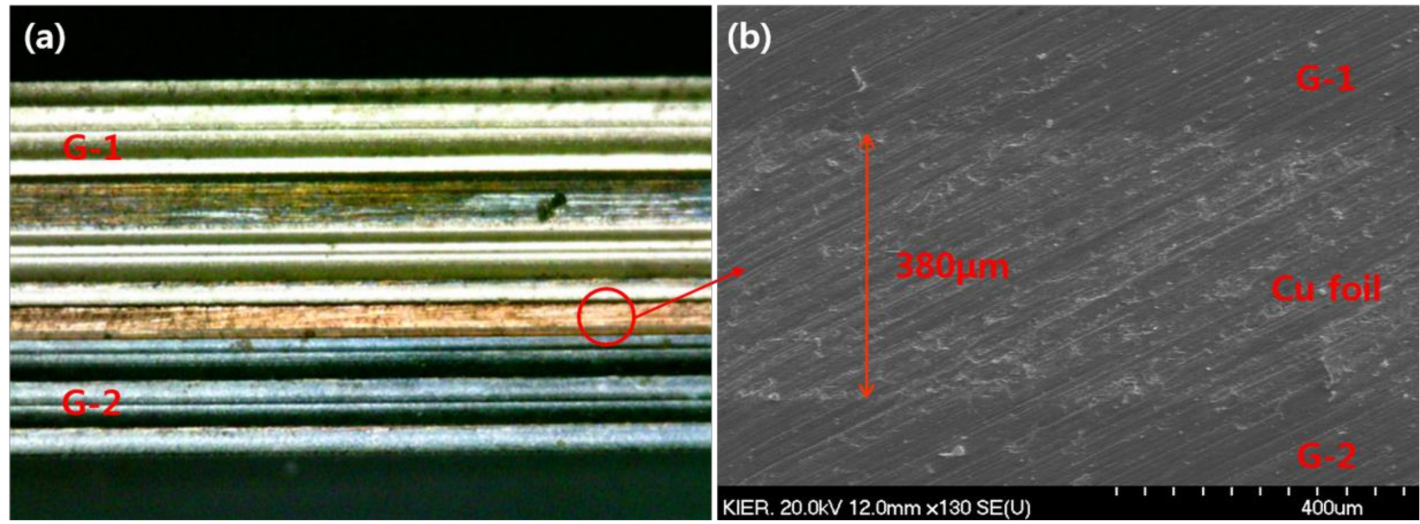

Figure 5. The cross-sectional image of diffusion bonded CPMM; (a) photograph, (b) SEM image of diffusion bonded layer. 


\subsection{Hydrogen Permeation Test of the CPMM}

The leak test of the CPMM installed with the palladium membrane was carried out using the $\mathrm{N}_{2}$ at room temperature. $\mathrm{N}_{2}$ of the permeate stream was not detected at a pressure difference of 1 bar and at room temperature. After confirming the leak-tightness of the CPMM, we carried out various performance tests. The performance of the membrane may be expressed in terms of a flux and selectivity as defined by Equations (1) and (2), respectively:

$$
\text { Flux }=F / A
$$

$\mathrm{H}_{2}$ Selectivity $=\mathrm{H}_{2}$ flow in permeate stream $/ \mathrm{N}_{2}$ flow in permeate stream

where $F$ represents the $\mathrm{H}_{2}$ flow through the membrane in the permeate stream and $A$ is the effective area of the membrane $\left(\mathrm{cm}^{2}\right)$.

We fabricated CPMM by diffusion bonding carried out a long-term stability test at a pressure difference of 1 bar and $400{ }^{\circ} \mathrm{C}$. As shown in Figure S2, the $\mathrm{H}_{2}$ permeation and $\mathrm{H}_{2}$ selectivity remained constant for $\sim 365 \mathrm{~h}$. Figure 6 shows the $\mathrm{H}_{2}$ permeation flux and selectivity using the pure gas and the flux and concentration of $\mathrm{H}_{2}$ in the permeation using the $\mathrm{H}_{2} / \mathrm{CO}_{2}$ mixture gas as a function of pressure difference at $400{ }^{\circ} \mathrm{C}$. As shown Figure $6 \mathrm{a}$, The $\mathrm{H}_{2}$ permeation flux significantly increased with pressure difference. The driving force for $\mathrm{H}_{2}$ separation is the pressure difference between the retentate and permeate. The flux of $\mathrm{H}_{2}$ through the CPMM ranged from 18.3 to $196.3 \mathrm{~mL} \mathrm{~cm}^{-2} \mathrm{~min}^{-1}$, depending on the pressure difference (1-20 bar). However, the $\mathrm{H}_{2} / \mathrm{N}_{2}$ selectivity significantly decreased from 1138 to 208 as the pressure difference was increased from 1 to 20 bar. The decrease in $\mathrm{H}_{2} / \mathrm{N}_{2}$ selectivity is considered to be due to the generated palladium fracture and defect of the membrane surface during the diffusion bonding of the CPMM. As shown in Figure $6 \mathrm{~b}$, the $\mathrm{H}_{2}$ separation test was performed using the $60 \% \mathrm{H}_{2} / 40 \% \mathrm{CO}_{2}$ mixture gas. The $\mathrm{H}_{2}$ separation capacity of the CPMM was examined with the $\mathrm{H}_{2} / \mathrm{CO}_{2}$ mixture gas flow rate of $1.0-1.5 \mathrm{~L} \mathrm{~min}^{-1}$ at $400{ }^{\circ} \mathrm{C}$ and a pressure difference ranging from 5 to 20 bar. The $\mathrm{H}_{2}$ flux increases with increasing pressure in the retentate stream. However, the $\mathrm{H}_{2}$ concentration decreases with increasing pressure due to $\mathrm{H}_{2} / \mathrm{N}_{2}$ selectivity, as shown in Figure 6 a. The $\mathrm{H}_{2}$ concentration was $>99 \%$ and $\mathrm{H}_{2}$ flux was $34.7 \mathrm{~mL} \mathrm{~cm}^{-2} \mathrm{~min}^{-1}$ in the permeate stream when the feed rate was $1.5 \mathrm{~L} \mathrm{~min}^{-1}$ and the pressure difference was $10 \mathrm{bar}$.

Figure 7 shows the drawing of multi stacked CPMM. The capacity of the multi stacked CPMM can be increased by scaling up the unit modules, as shown in Figure 7. The $\mathrm{H}_{2}$ flow of $2.1 \mathrm{~L} \mathrm{~min}^{-1}$ with $\mathrm{H}_{2}$ concentration of $>99 \%$ will be produced by the multi-stacking membrane module with four membranes. Moreover, the module height is $25.6 \mathrm{~mm}$ and the module volume is $122.8 \mathrm{~cm}^{3}$. The module volume was $553.4 \mathrm{~cm}^{3}$ in the case of the frame-type membrane module with four membranes pre-studied in our laboratory [17]. The volume of multi stacked CPMM will be able to decrease by $77.8 \%$ at using the four membranes, compared with the frame-type membrane module.

Figure 8 shows the surface SEM images of the fresh and used palladium membranes in the CPMM. As shown Figure 8a, The surface of the fresh membrane was clear. However, despite diffusion bonding at a relatively low-temperature of $450{ }^{\circ} \mathrm{C}$, some palladium fracture were partially formed on the surface of the palladium membrane, as seen in Figure $8 \mathrm{~b}$. This result indicates that the membrane morphology is affected and some sintering occurs on the top layer of the palladium membrane even when diffusion bonding is carried out at a low-temperature of $450{ }^{\circ} \mathrm{C}$ under high-vacuum conditions. 

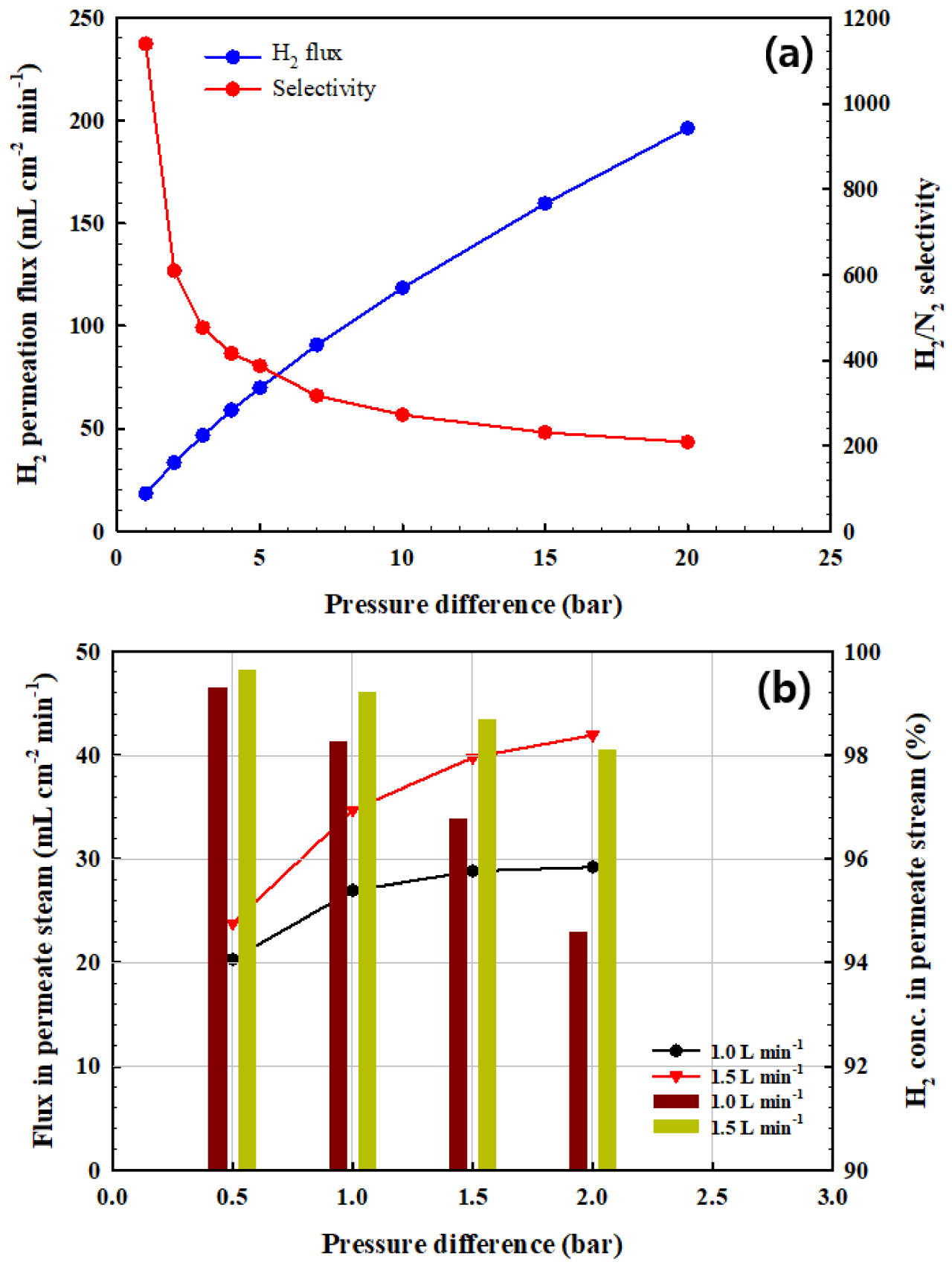

Figure 6. The performance test of CPMM as a function of pressure difference at the temperature of $400{ }^{\circ} \mathrm{C}$; (a) the hydrogen permeation flux and $\mathrm{H}_{2} / \mathrm{N}_{2}$ selectivity, (b) the flux and $\mathrm{H}_{2}$ concentration of permeation gas using the $\mathrm{H}_{2} / \mathrm{CO}_{2}$ mixture gas; vertical bar plot: $\mathrm{H}_{2}$ concentration, line plot: $\mathrm{H}_{2}$ flux. 


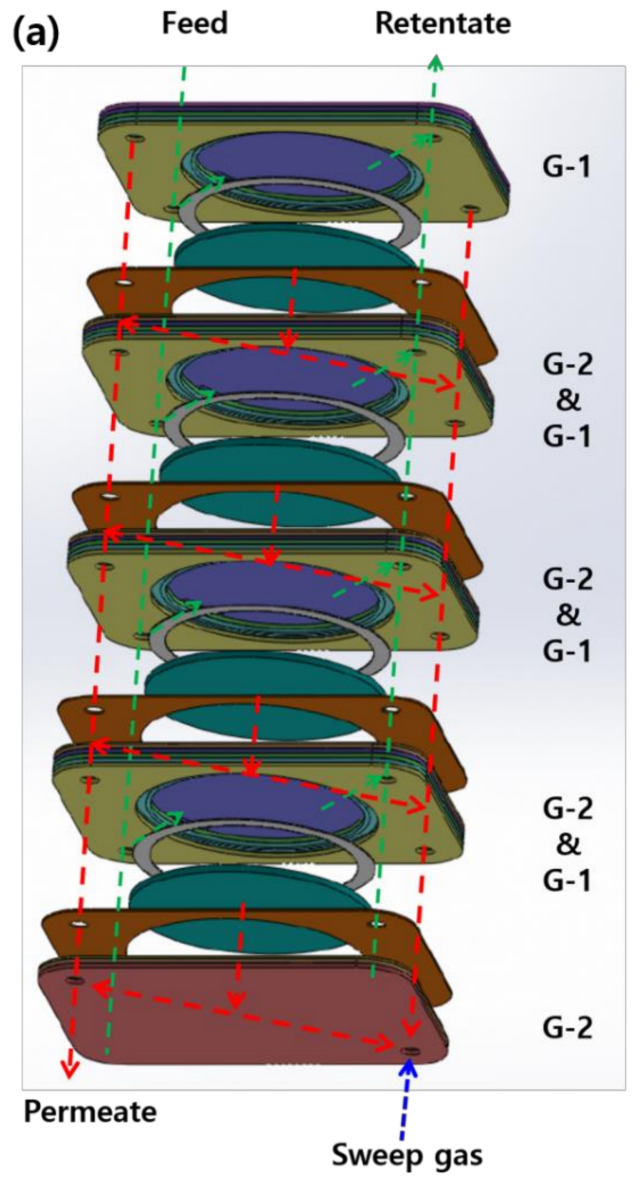

(b)

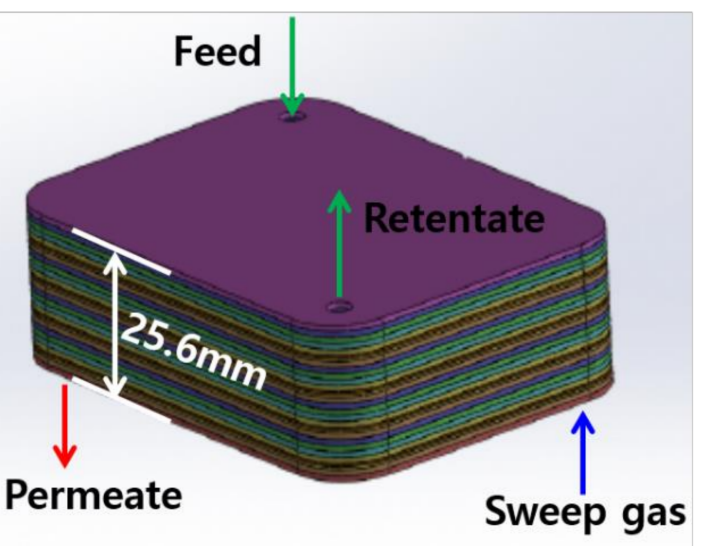

(c)

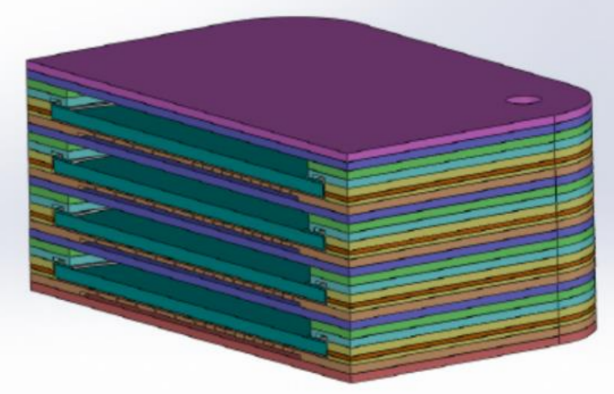

Figure 7. The schematic drawing of multi stacked CPMM; (a) layout of the gas path in the CPMM, (b) multi stacked CPMM, (c) cross-section of multi stacked CPMM.

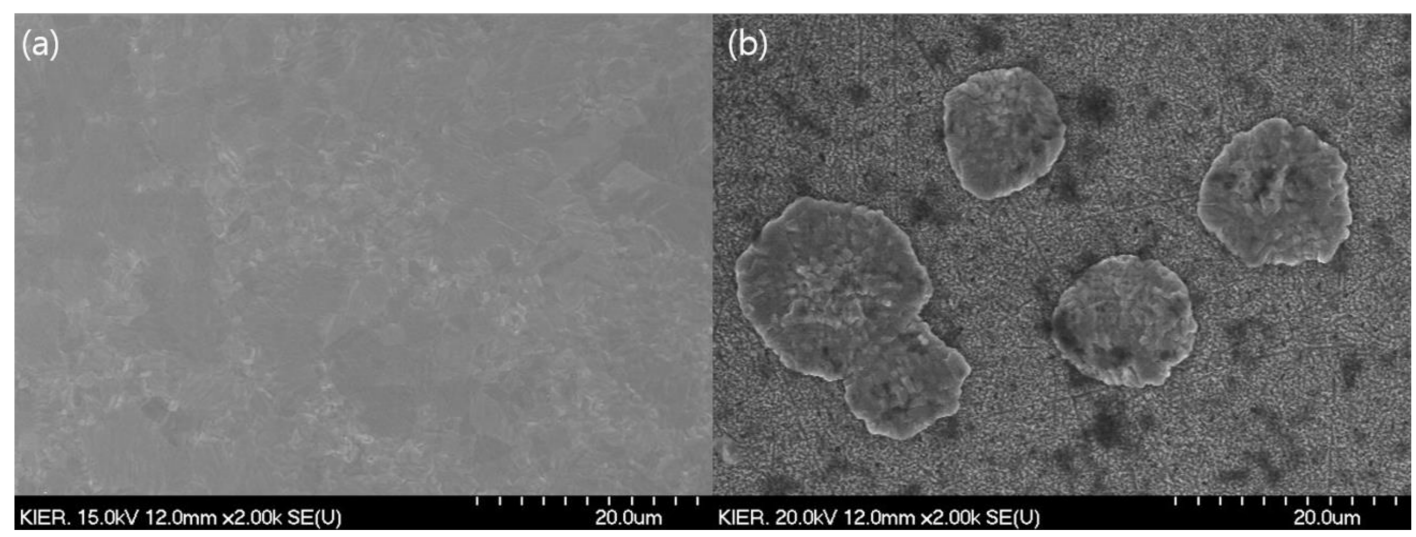

Figure 8. The surface SEM image of Palladium membrane; (a) fresh membrane, (b) membrane after the diffusion bonding and permeation test.

\section{Conclusions}

The CPMM was prepared and constructed for $\mathrm{H}_{2}$ separation. The G-1 and G-2 groups were prepared after the high-temperature diffusion bonding to reduce damage to the membrane. Next, the G-1 and G-2 groups was modified for low-temperature diffusion bonding of the module. The effective diffusion bonding area of the surface of the 316L SS plate was increased using peening, $\mathrm{Ni}-\mathrm{Cu}$ deposition, and thermal treatment, resulting in perfect diffusion bonding of the membrane 
module at low-temperatures. The diffusion bonded module was obtained by height $7.9 \mathrm{~mm}$, and volume $37.9 \mathrm{~cm}^{3}$. In addition, the volume of the diffusion bonded module than the pre-studied frame-type module were decreased by $81.4 \%$ [23]. Even though diffusion bonding was entirely performed at a low-temperature of $450{ }^{\circ} \mathrm{C}$, a Palladium fracture was generated due to high-vacuum conditions on the membrane surface. The $\mathrm{H}_{2}$ permeation flux and the $\mathrm{H}_{2} / \mathrm{N}_{2}$ selectivity tests were conducted at a pressure difference of 1 bar, and a $\mathrm{H}_{2}$ flux of $18.3 \mathrm{~mL} \mathrm{~cm}^{-2} \mathrm{~min}^{-1}$ and $\mathrm{H}_{2} / \mathrm{N}_{2}$ selectivity of 1138 at $400{ }^{\circ} \mathrm{C}$ were observed in the CPMM. In the hydrogen separation test of $\mathrm{H}_{2} / \mathrm{CO}_{2}$ mixture gas, the $\mathrm{H}_{2}$ flux was $34.7 \mathrm{~mL} \mathrm{~cm}^{-2} \mathrm{~min}^{-1}$ and the $\mathrm{H}_{2}$ concentration was confirmed to be over $99.0 \%$. However, the $\mathrm{H}_{2} / \mathrm{N}_{2}$ selectivity of the membrane decreased with increasing pressure difference. In the present study, we suggest that the CPMM can be used for compact $\mathrm{H}_{2}$ purifier. Further research is needed on the assembly methods to minimize membrane damage.

Supplementary Materials: The following are available online at http://www.mdpi.com/2077-0375/10/11/338/s1, Figure S1: Long-term stability test of CPMM; Temperature was $400^{\circ} \mathrm{C}$; Pressure difference was 1 bar, Figure S2: Cross-sectional image of the prepared membrane; (a) FE-SEM, (b) FE-SEM/EDS.

Author Contributions: D.-K.O. (methodology, data curation, writing original draft preparation, formal analysis), K.-Y.L. (supervision), and J.-S.P. (conceptualization, writing, reviewing, and editing, project administration, funding acquisition). All authors have read and agreed to the published version of the manuscript.

Funding: This work was supported by the Research and Development Program of the Korea Institute of Energy Research (KIER) (Project No. B6-2451), Republic of Korea.

Acknowledgments: This work was supported by the Research and Development Program of the Korea Institute of Energy Research (KIER) (Project No. B6-2451), Republic of Korea.

Conflicts of Interest: The authors declare no conflict of interest.

\section{References}

1. Xiao, Y.; Chung, T.S. Grafting thermally labile molecules on cross-linkable polyimide to design membrane materials for natural gas purification and $\mathrm{CO}_{2}$ capture. Energy Environ. Sci. 2011, 4, 201-208. [CrossRef]

2. Authayanun, S.; Aunsup, P.; Patcharavorachot, Y.; Arpornwichanop, A. Theoretical analysis of a biogas-fed PEMFC system with different hydrogen purifications: Conventional and membrane-based water gas shift processes. Energy Convers. Manag. 2014, 86, 60-69. [CrossRef]

3. Alenazey, F.; Alyousef, Y.; Almisned, O.; Almutairi, G.; Ghouse, M.; Montinaro, D.; Ghigliazza, F. Production of synthesis gas $\left(\mathrm{H}_{2}\right.$ and $\left.\mathrm{CO}\right)$ by high-temperature Co-electrolysis of $\mathrm{H}_{2} \mathrm{O}$ and $\mathrm{CO}_{2}$. Int. J. Hydrogen Energy 2015, 40, 10274-10280. [CrossRef]

4. Rothenberger, K.S.; Cugini, A.V.; Howard, B.H.; Killmeyer, R.P.; Ciocco, M.V.; Morreale, B.D.; Enick, R.M.; Bustamante, F.; Mardilovich, I.P.; Ma, Y.H. High pressure hydrogen permeance of porous stainless steel coated with a thin palladium film via electroless plating. J. Membr. Sci. 2004, 244, 55-68. [CrossRef]

5. Armaroli, N.; Balzani, V. The hydrogen issue. ChemSusChem 2011, 4, 21-36. [CrossRef]

6. Shimura, K.; Yoshida, H. Heterogeneous photocatalytic hydrogen production from water and biomass derivatives. Energy Environ. Sci. 2011, 4, 2467-2481. [CrossRef]

7. Holladay, J.D.; Hu, J.; King, D.L.; Wang, Y. An overview of hydrogen production technologies. Catal. Today. 2009, 139, 244-260. [CrossRef]

8. Schell, J.; Casas, N.; Marx, D.; Mazzotti, M. Precombustion $\mathrm{CO}_{2}$ capture by pressure swing adsorption (PSA): Comparison of laboratory PSA experiments and simulations. Ind. Eng. Chem. Res. 2013, 52, 8311-8322. [CrossRef]

9. You, Y.W.; Lee, D.G.; Yoon, K.Y.; Moon, D.K.; Kim, S.M.; Lee, C.H. H$_{2}$ PSA purifier for CO removal from hydrogen mixtures. Int. J. Hydrogen Energy 2012, 37, 18175-18186. [CrossRef]

10. Chen, W.H.; Hsu, P.C. Hydrogen permeation measurements of Pd and Pd-Cu membranes using dynamic pressure difference method. Int. J. Hydrogen Energy 2011, 36, 9355-9366. [CrossRef]

11. Psara, N.; Van Sint Annaland, M.; Gallucci, F. Hydrogen safety risk assessment methodology applied to a fluidized bed membrane reactor for autothermal reforming of natural gas. Int. J. Hydrogen Energy 2015, 40, 10090-10102. [CrossRef] 
12. Tong, J.; Suda, H.; Haraya, K.; Matsumura, Y. A novel method for the preparation of thin dense Pd membrane on macroporous stainless steel tube filter. J. Membr. Sci. 2005, 260, 10-18. [CrossRef]

13. Mardilovich, I.P.; Castro-Dominguez, B.; Kazantzis, N.K.; Wu, T.; Ma, Y.H. A comprehensive performance assessment study of pilot-scale Pd and Pd/alloy membranes under extended coal-derived syngas atmosphere testing. Int. J. Hydrogen Energy 2015, 40, 6107-6117. [CrossRef]

14. Ryi, S.K.; Park, J.S.; Kim, S.H.; Cho, S.H.; Kim, D.W. The effect of support resistance on the hydrogen permeation behavior in Pd-Cu-Ni ternary alloy membrane deposited on a porous nickel support. J. Membr. Sci. 2006, 280, 883-888. [CrossRef]

15. Kurokawa, H.; Yakabe, H.; Yasuda, I.; Peters, T.; Bredesen, R. Inhibition effect of CO on hydrogen permeability of Pd-Ag membrane applied in a microchannel module configuration. Int. J. Hydrogen Energy 2014, 39, 17201-17209. [CrossRef]

16. Xie, D.; Yu, J.; Wang, F.; Zhang, N.; Wang, W.; Yu, H.; Peng, F.; Park, A.H.A. Hydrogen permeability of Pd-Ag membrane modules with porous stainless steel substrates. Int. J. Hydrogen Energy 2011, 36, 1014-1026. [CrossRef]

17. Ryi, S.K.; Park, J.S.; Hwang, K.R.; Lee, C.B.; Lee, S.W. The property of hydrogen separation from $\mathrm{CO}_{2}$ mixture using Pd-based membranes for carbon capture and storage (CCS). Int. J. Hydrogen Energy 2013, 38, 7605-7611. [CrossRef]

18. Borgognoni, F.; Tosti, S. Multi-tube Pd-Ag membrane module for pure hydrogen production: Comparison of methane steam and oxidative reforming. Int. J. Hydrogen Energy 2013, 38, 8276-8284. [CrossRef]

19. Maneerung, T.; Hidajat, K.; Kawi, S. Ultra-thin $(<1 \mu \mathrm{m})$ internally-coated Pd-Ag alloy hollow fiber membrane with superior thermal stability and durability for high temperature H2 separation. J. Membr. Sci. 2014, 452, 127-142. [CrossRef]

20. Ryi, S.K.; Park, J.S.; Choi, S.H.; Cho, S.H.; Kim, S.H. Novel micro fuel processor for PEMFCs with heat generation by catalytic combustion. Chem. Eng. J. 2005, 113, 47-53. [CrossRef]

21. Li, S.X.; Xuan, F.Z.; Tu, S.T.; Yu, S.R. Microstructure evolution and interfacial failure mechanism in 316LSS diffusion-bonded joints. J. Mater. Sci. Eng. A. 2008, 491, 488-491. [CrossRef]

22. Hwang, K.R.; Ryi, S.K.; Lee, C.B.; Lee, S.W.; Park, J.S. Simplified, plate-type Pd membrane module for hydrogen purification. Int. J. Hydrogen Energy 2011, 36, 10136-10140. [CrossRef]

23. Lee, S.W.; Oh, D.K.; Park, J.W.; Lee, C.B.; Lee, D.W.; Park, J.S.; Kim, S.H.; Hwang, K.R. Effect of a Pt-ZrO protection layer on the performance and morphology of $\mathrm{Pd}-\mathrm{Au}$ alloy membrane during $\mathrm{H}_{2} \mathrm{~S}$ exposure. J. Alloys Compd. 2015, 641, 210-215. [CrossRef]

24. Hwang, K.R.; Lee, S.W.; Ryi, S.K.; Kim, D.K.; Kim, T.H.; Park, J.S. Water-gas shift reaction in a plate-type Pd-membrane reactor over a nickel metal catalyst. Fuel Process. Technol. 2013, 106, 133-140. [CrossRef]

Publisher's Note: MDPI stays neutral with regard to jurisdictional claims in published maps and institutional affiliations.

(C) 2020 by the authors. Licensee MDPI, Basel, Switzerland. This article is an open access article distributed under the terms and conditions of the Creative Commons Attribution (CC BY) license (http://creativecommons.org/licenses/by/4.0/). 